\title{
STRUKTUR KOMUNITAS IKAN TARGET DI EKOSISTEM TERUMBU KARANG PADA ZONA TRADISIONAL PULAU BUNAKEN, TAMAN NASIONAL BNAKEN
}

\author{
(Target Fish Communities in Coral Reef Ecosystem in The Tradisional Zone of \\ Bunaken Island)
}

\section{Meilisa Mandolang ${ }^{1 *}$, Janny D. Kusen ${ }^{2}$, Veibe Warouw ${ }^{2}$, Erly Y. Kaligis ${ }^{2}$, James H. Paulus $^{2}$, Unstain N.W.J. Rembet ${ }^{3}$}

1. Mahasiswa Program Studi IImu Kelautan, FPIK, UNSRAT Manado

2. Staf Pengajar Program Studi IImu Kelautan, FPIK, UNSRAT Manado

3. Staf Pengajar Program Studi Manajemen Sumberdaya Perairan, FPIK UNSRAT Manado

Penulis korespondensi: Meilisa Mandolang; melmandolang@gmail.com

This study aims to determine the structure of the target fish community, including species composition, type of research and to analyze the ecological index in which the diversity index, uniformity index, dominance index, and community similarity index. Data collection was carried out in coral reef ecosystems in the traditional zones of Madolin, Alung Banua, Sachiko, Muka Kampung, and East Bunaken areas, all data collection areas were included in the Bunaken National Park area. Data was taken using the Underwater Visual Census method, also equipped with a documentation search for underwater photography and videography carried out at the Marine Biology laboratory, Faculty of Fisheries and Marine Sciences, UNSRAT. There are 3 families, 21 species and 130 individuals at the Madolin area, 5 families, 24 species, and 72 individuals at the Alung Banua area, 5 families, 23 species, and 77 individuals at the Sachiko area, 2 families, 11 species and 129 individuals at the Sachiko area. Muka Kampung, and 4 families, 18 species, and 160 individuals at the East Bunaken location. The calculated ecological index values obtained are H' 2.11 (Madolin), 2.90 (Alung Banua), 2.65 (Sachiko), 1.57 (Muka Kampung), 1.67 (East Bunaken) indicating the ecological condition of the ecosystem. coral reefs are still stable even though diversity is classified as moderate but inversely proportional to low dominance ranging from 0.07 to 0.33 on average. The results of the community similarity analysis using the Sorense index $(<50 \%)$ showed that there was no similarity in reef fish communities between the 4 stations, namely (Madolin \& Alung Banua), (Madolin \& Muka Kampung), and (Muka Kampung \& East Bunaken).

Keywords : target fish community, diversity, dominance, community similarity.

Penelitian ini bertujuan untuk mengetahui struktur komunitas ikan target, didalamnya meliputi komposisi jenis, kelimpahan jenis serta menganalisisi indeks ekologi komunitas didalamnya indeks keanekaragaman, indeks keseragaman, indeks dominansi, dan indeks kesamaan komunitas. Pengambilan data dilakukan di ekosistem terumbu karang pada zona tradisional wilayah Madolin, Alung Banua, Sachiko, Muka Kampung, dan Bunaken Timur, seluruh wilayah pengambilan data adalah termasuk dalam wilayah Taman Nasional Bunaken. Data diambil dengan menggunakan metode Sensus Visual Bawah Air juga dilengkapi dengan telusur dokumentasi hasil fotografi dan videografi bawah air yang dilaksanakan di laboratorium Biologi Kelautan, Fakultas Perikanan dan IImu Kelautan UNSRAT. Terdapat 3 famili, 21 spesies serta 130 individu pada lokasi Madolin, 5 famili, 24 spesies, serta 72 individu pada lokasi Alung Banua, 5 faimili, 23 spesies, serta 77 individu pada lokasi Sachiko, 2 famili, 11 spesies serta 129 individu pada lokasi Muka Kampung, dan 4 famili, 18 spesies, serta 160 individu pada lokasi Bunaken Timur. Nilai perhitungan indeks ekologi yang diperoleh yaitu H’ 2,11 (Madolin), 2,90 (Alung Banua), 2,65 (Sachiko), 1,57 (Muka Kampung), 1,67 (Bunaken Timur) menunjukkan kondisi ekologi ekosistem terumbu karang masih stabil sekaliput keanekaragaman tergolong sedang tapi berbanding terbalik dengan dominansi yang rendah berkisar rata-rata antara 0,07-0,33. Hasil analisis kesamaan komunitas menggunakan indeks Sorense yaitu $(<50 \%)$ menunjukkan tidak terdapat kesamaan komunitas ikan karang antara 4 stasiun yaitu (Madolin \& Alung Banua), (Madolin \& Muka Kampung), dan (Muka Kampung \& Bunaken Timur).

Kata Kunci : komunitas ikan target, keanekaragaman, dominasi, kemerataan kesamaan komunitas 


\section{PENDAHULUAN}

Taman Nasional Bunaken (TNB) adalah kawasan pelestarian alam berbasis perairan yang dikelola oleh pemerintah dan ditetapkan berdasarkan SK. Menteri Kehutanan No. 730/KPTSII/1991 dengan luas $89.065 \mathrm{Ha}$. Taman Nasional Bunaken juga mempunyai Zona Tradisional yang profit fisiografinya yaitu Rataan Terumbu (Reef Flat) (Setiawan dkk. 2013). Zona tradisional sebagai bagian dari Taman Nasional yang ditetapkan untuk kepentingan pemanfaatan secara tradisional oleh masyarakat yang karena kesejahteraannya tergantung dengan sumber daya alam yang ada disitu.

Ekosistem terumbu karang merupakan salah satu ekosistem pesisir dengan biodiversitas yang tinggi. Keunikan ekosistem serta keragaman organismenya menjadikan ekosistem terumbu karang memiliki nilai ekonomis, ekologi, bahkan sosial yang tinggi (Toruan, 2011). Terumbu karang merupakan suatu ekosistem yang kompleks dalam ekologi laut dimana di dalamnya hidup biota-biota yang berasosiasi dengan karang. Keberadaan ikan karang dipengaruhi oleh kondisi atau kualitas karang sebagai habitatnya (Dartnall dan Jones, 1986).

Ikan karang merupakan salah satu komoditi unggulan perikanan, maka perlu dilakukan pengawasan agar stok ikan di alam masih dapat terjaga dengan lestari. Adapun dalam melakukan monitoring ikan karang bertujuan untuk melihat perubahan ekosistem ikan karang setiap tahun.

Keberadaan ikan karang telah menjadikan ekosistem terumbu karang sebagai ekosistem yang paling banyak dihuni biota. Tingginya keragaman ini disebabkan terdapatnya variasi habitat yang ada di terumbu karang, dimana semua tipe habitat tersebut diisi oleh spesies ikan karang (Rembet $d k k$. 2011).

Salah satu kebanggaan utama Provinsi Sulawesi Utara adalah keindahan Taman Nasional Bunaken dengan ekosistem terumbu karang, juga dengan biota yang berasosiasi dengan karang salah satunya ikan karang, namun dari hasil penelitian pada Tahun 2013 oleh Setiawan dkk (2013), menunjukkan bahwa presentasi tutupan karang hidup di wilayah Taman Nasional Bunaken tergolong dalam kategori sedang dengan nilai rata-rata $(25-49,9 \%)$. Menurut Makatipu dkk (2010), rendahnya tutupan karang di beberapa lokasi di TNB disebabkan oleh pernah dilakukannya penangkapan ikan dengan cara merusak oleh masyarakat serta letaknya yang berada di daerah terbuka, sehingga pada musim tertentu berombak sangat keras.

Sehubungan dengan hal-hal tersebut di atas maka perlu dilakukan tindakan untuk mencegah meningkatnya degradasi terumbu karang dengan melakukan pemantauan (monitoring). Pemantauan ini bisa dilakukan dengan melihat ikan-ikan yang ada di area terumbu karang. Salah satu cara atau teknik pemantauan terhadap keberadaan ikan karang yaitu meggunakan metode Sensus Visual bawah air.

\section{METODE PENELITIAN}

Pelaksanaan kegiatan pengambilan data ikan target di lapangan berlangsung selama 2 (dua) hari dan dilakukan di Zona Tradisional Pulau Bunaken Provinsi Sulawesi Utara, dengan 5 stasiun pengamatan yaitu Madolin pada titik koordinat N 1036'49.58" E 1244ㅇ'56.53", Alung Banua N 137'47.00"

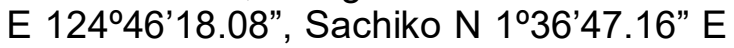
124\%4'1.90", Muka Kampung N

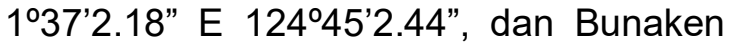
Timur N 1'35'50.48” E 124²6'11.26”. 


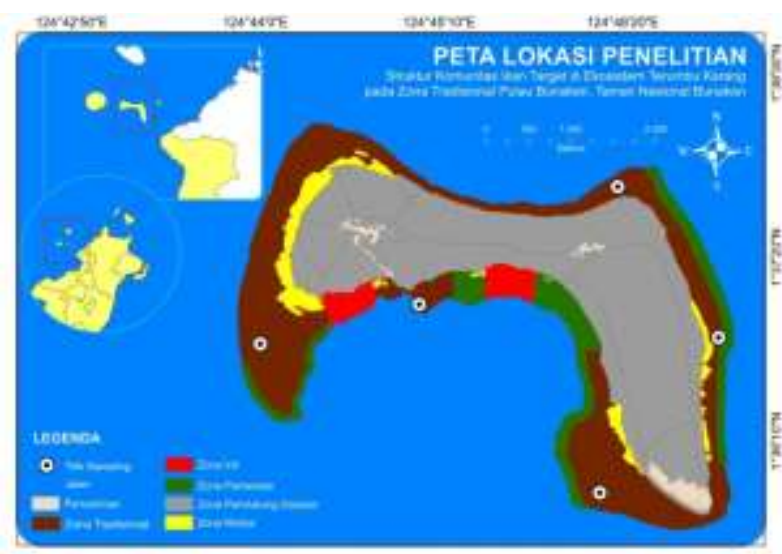

Gambar 1. Peta lokasi penelitian

Pengambilan data ikan target dilakukan dengan menggunakan motode sensus visual bawah air Underwater Visual Census UVC (English, dkk 1994), dimana di setiap stasiun pada kedalaman 5-6 meter diletakkan transek berukuran 100 meter sebagai patokan dalam pengambilan data. Data yang diperoleh adalah jumlah spesies dan jumlah individu masing-masing spesies ikan target. Hasil pengamatan dan pencatatan yang didapatkan dijadikan bahan untuk melihat struktur komunitas ikan target. Untuk menganalisis struktur komunitas ikan target, maka data tersebut dianalisis dengan melihat komposisi, kelimpahan serta indeks ekologi di dalamnya yaitu indeks keanekaragaman, indeks keseragaman, indeks dominansi, serta indeks kesamaan komunitas.

\section{a. Analisa Data}

Setelah selesai untuk pengumpulan data selanjutnya melihat komposisi dan kelimpahan dari ikan target, juga menganalisis data dengan cara menghitung indeks-indeks dalam struktur komunitas berupa indeks keanekaragaman, keseragaman, dominansi, dan kesamaan komunitas dari kelima lokasi penelitian. Indeks-indeks tersebut yaitu :

\section{Indeks Keanekaragaman}

Indeks Keanekaragaman ( $\left.\mathrm{H}^{\prime}\right)$ dapat diartikan sebagai suatu penggambaran secara sistematik yang melukiskan struktur komunitas dan dapat memudahkan proses analisis informasiinformasi mengenai macam dan jumlah organisme. Selain itu keanekaragaman dan keseragaman sangat tergantung pada banyaknya spesies dalam komunitasnya. Semakin banyak jenis yang ditemukan maka keanekaragaman akan semakin besar, meskipun nilai ini sangat tergantung dari jumlah individu masingmasing jenis (Wilhm dan Doris, 1986). Perhitungan untuk keanekaragaman menggunakan indeks keanekaragaman Shanon-Wiener (H') (Soegianto, 1994).

\section{Indeks Keseragaman}

Indeks keseragaman (E) adalah komposisi setiap individu pada suatu spesies yang terdapat dalam suatu komunitas. Semakin merata penyebaran individu antar spesies maka keseimbangan ekosistem akan semakin meningkat. Indeks keseragaman merupakan pendugaan yang baik untuk menentukan dominasi dalam suatu area (Levinton,1982). Nilai Indeks keseragaman jenis dapat menggambarkan kestabilan suatu komunitas..

\section{Indeks Dominansi}

Menurut Suheryanto (2008), suatu kondisi yang beragaman, satu jenis tidak dapat menjadi lebih dominan dari yang lainnya, sedangkan apabila satu atau dua jenis mencapai kepadatan yang lebih besar dibandingkan dengan lainnya maka komunitas itu memiliki kondisi yang kurang beragam. Dominansi adalah perbandingan jumlah individu dalam suatu jenis dengan jumlah total individu seluruh jenis. 


\section{Indeks Kesamaan Komunitas}

Kendeight (1974) menyatakan suatu aturan 50\%, yaitu dua komunitas dinyatakan sama jika memiliki nilai kesamaan sama atau lebih besar dari $50 \%$. Berdasarkan hasil penelitian dari Rahman \& Sugianti (2011) menyatakan bahwa Nilai koefisien kesamaan spesies dari 7 lokasi pengambilan data berkisar 29,51 - 51,85\%. Oleh karena itu makin besar nilai koefisien yang diperoleh berarti makin besar kesamaan komunitas yang dibandingkan. Analisis dengan menggunakan indeks kesamaan komunitas menyatakan terdapat perbedaan antara dua stasiun pengamatan dan diperkirakan keadaan tersebut dapat terjadi karena adanya beberapa faktor yang mempengaruhi seperti pengaruh dari darat ke leut atau dapat dikatakan kondisi lingkungan serta kegiatan antropogenik (Sumual $d k k$. 2018).

\section{HASIL DAN PEMBAHASAN}

\section{Komposisi dan Kelimpahan ikan target}

Jenis-jenis ikan target yang dijumpai di lokasi penelitian. Terdapat 48 jenis spesies ikan target, yang berasal dari 7 famili ikan karang. Madolin terdapat 21 spesies, Alung Banua terdapat 24 spesies, Sachiko terdapar 23 spesies, Muka Kampung terdapat 11 spesies, sedangkan Bunaken Timur terdapat 18 spesies. Hanya 4 spesies ikan karang yang ditemukan di lima lokasi penelitian, yaitu Acanthurus auranticavus, Acanthurus lineautus, Ctenochaetus striatus, dan Zebrasoma scopas. Menurut Bell dan Galzin (1984), faktor-faktor yang mempengaruhi kehadiran ikan di suatu komunitas terumbu karang, antara lain tinggi rendahnya presentase tutupan karang hidup dan zona habitat (inner reef flat, outer reef flat, crest, reef base, sand flat). Secara umum, kelimpahan ikan karang di stasiun Bunaken Timur paling tinggi yaitu 160 individu dibandingkan dengan stasiun lainnya yaitu Madolin sebanyak 130 individu, Alung Banua sebanyak 72 individu Sachiko sebanyak
23 individu, dan Muka Kampung sebanyak 129 individu. Jumlah individu ikan karang karang yang ditemukan di lokasi penelitian sangat berpengaruh terhadap tinggi rendahnya kelimpahan ikan karang. Secara tidak langsung menurut McMellor (2007), menyatakan kondisi lingkungan juga sangat berpengaruh terhadap kelimpahan ikan-ikan yang hidup di terumbu karang tersebut. Kondisi jenis dan kelimpahan individu ikan karang berkurang secara signifikan ketika tutupan karang mati dan pecahan karang sangat tinggi sehingga akan memperburuk populasi ikan karang. Selain itu suhu dan salinitas juga berdampak terhadap kondisi terumbu karang sehingga berpengaruh terhadap populasi ikan karang.

\section{Indeks Keanekaragaman}

Berdasarkan hasil analisis data ikan karang di semua stasiun, di dapatkan hasil nilai indeks keanekaragaman ( $\left.\mathrm{H}^{\prime}\right)$. Pada stasiun Madolin nilai $\mathrm{H}^{\prime}$ adalah 2,11, Alung Banua 2,90, Sachiko 2,65, Muka Kampung 1,57 dan Bunaken Timur 1,67. Odum (1998) menyatakan bahwa makin besar nilai $\left(\mathrm{H}^{\prime}\right)$ menunjukan komunitas makin beragam. Dengan kisaran nilai indeks keanekaragaman, kestabilan komunitas ikan target pada stasiun BIK 01, BIK 02, dan BIK 03 sedang, sedangkan kestabilan komunitas ikan target pada nilai stasiun BIK 04 dan BIK 05 rendah, karena sesuai dengan kriteria penilaian menurut Barbour, dkk (1987) jika $1<\mathrm{H}^{\prime}<3$ keanekaragaman sedang dan jika H' < 1 Menunjukkan keanekaragaman rendah. Nybakken (1990) menjelaskan bahwa keanekaragaman spesies tinggi, merupakan petunjuk lingkungan yang nyaman dan stabil, sedangkan nilai keanekaragaman yang rendah menandakan lingkungan yang menyesakkan dan berubah-ubah.

\section{Indeks Dominansi}

Nilai indeks dominansi (D) berkisar antara 0-1, dimana semakin besar nilainya maka terdapat kecenderungan spesies tertentu mendominasi populasi (Ludwig dan Reynolds, 1988). Nilai indeks dominansi dari analisisi data ikan karang pada BIK 01, BIK 02, BIK 03, BIK 04 dan 
BIK 05 berkisar rata rata antara 0,07 0,33 (Lampiran 10-14). Menurut Barbour, dkk (1987), apabilah kisaran nilai indeks dominansi antara 0,75 - 1,00 dengan pengertian bahwa akan terjadi dominansi jenis yang tinggi, jika nilainya diantara 0,50 - 0,75 bahwa dominansi jenis dikatakan sedang. Berdasarkan hasil nilai dominansi kelima stasiun penelitian secara umum dapat dikategorikan dominansi spesies ikan target rendah. Hal ini sesuai dengan yang dikemukakan Barbour, dkk (1987) bahwa nilai $D<0,50$ menunjukan dominansi spesies yang rendah.

\section{Indeks Keseragaman}

Berdasarkan hasil analisis data ikan karang di semua stasiun, di dapatkan hasil nilai indeks keseragaman pada stasiun Madolin 0,69, Alung Banua 0,91, Sachiko 0,85, Muka Kampung 0,65, dan Bunaken Timur adalah 1,67. Odum (1998) menyatakan bahwa makin besar nilai $(E)$ menunjukkan komunitas ikan karang makin beragam begitupun sebaliknya. Nilai indeks keseragaman stasiun Alung Banua dan Sachiko termasuk pada kategori komunitas labil sedangkan nilai indeks keseragaman stasiun Madolin, Muka Kampung, dan Bunaken Timur termasuk pada kategori komunitas tertekan. Ini menunjukkan bahwa spesies yang ditemukan tidak merata karna terdapat 3 (tiga) stasiun yg mempunyai nilai $\mathrm{E}<0,75$.

\section{Indeks Kesamaan}

Analisis perbandingan komunitas ikan karang antara lima lokasi, menunjukan hasil analisis kesamaan komunitas ikan karang dengan menggunakan koefesien kesamaan (Similatiry) sorensen dimana nilai kesamaan < 50\% menunjukkan kesamaan komunitasnya relative berbeda namun jika nilai kesamaan kisaran $>50 \%$ menunjukkan kesamaan nilai komunitas relative sama. Seperti yang telah dikemukakan oleh Samingan (1980), menyatakan bahwa komunitas tidak hanya mengalami kesatuan fungsional tertentu dengan struktur makan dan pola arus energi yang khas tetapi juga mempunyai kesatuan komposional dimana terdapat peluang bahwa jenis tertentu akan terdapat atau hidup berdampingan.

Secara keseluruhan profil struktur komunitas ikan karang pada 5 lokasi dapat terlihat pada gambar di bawah ini.

\begin{tabular}{|c|c|c|c|c|}
\hline \multirow{7}{*}{ 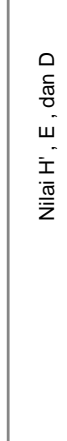 } & 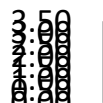 & & & \\
\hline & & $H^{\prime}$ & $E$ & D \\
\hline & $\nabla \mathrm{M}$ & 2.11 & 0.69 & 0.19 \\
\hline & $\square \mathrm{AB}$ & 2.90 & 0.91 & 0.07 \\
\hline & $\square S$ & 2.65 & 0.85 & 0.10 \\
\hline & 口MK & 1.57 & 0.65 & 0.28 \\
\hline & $\nabla \mathrm{BT}$ & 1.67 & 0.58 & 0.33 \\
\hline
\end{tabular}

Hal ini menunjukkan bahwa kondisi lingkungan bagi eksistensi ikan karang di kelima lokasi cukup stabil dengan nilai keanekaragaman $\left(H^{\prime}=1-3\right.$. kategori sedang) atau kondisi kualifikasi sedang, serta tidak ada jenis atau spesies yang mendominasi. Suatu lingkungan habitat di perairan tropis dengan keanekaragamn yang tinggi bisa dipahami bahwa banyak spesies yang berpeluang untuk berkembang biak secara alami dengan baik. Untuk kondisi ini tidak ada spesies yang dominan (atau mendominasi), sehingga menunjukkan keadaan lingkungan yang stabil bagi tempat tinggal (habitat) berbagai jenis atau spesies. Keanekaragaman yang tergolong sedang pada kelima stasiun menunjukkan adanya intervensi kegiatan dari luar ekosistem yang mempengaruhi. Diduga intervensi ini oleh kegiatan manusia (anthropogenic) seperti yang ada sekarang ini diperairan pulau Bunaken sekalipun status dari pulau bunaken masuk dalam ruang Taman Nasional Bunaken yang notabennya merupakan kawasan konservasi.

Analisis data dengan menggunakan indeks kesamaan yang dapat dilihat pada Lampiran yang dinyatakan pada semua stasiun. (Madolin \& Alung Banua) mendapatkan hasil 44,4\%, (Madolin \& Sachiko) dengan hasil nilai kesamaan yaitu 50,0\%, (Madolin \& Muka Kampung) 30,8\%, (Madolin \& Bunaken Timur) 
$51,3 \%$, (Alung Banua \& Sachiko) 51,1\%, (Alung Banua \& Muka Kampung) 57,1\%, (Alung Banua \& Bunaken Timur) 52,4\%, (Sachiko \& Muka Kampung) 70,6\%, (Sachiko \& Bunaken Timur) 58,5\%, dan (Muka Kampung \& Bunaken Timur) mendapatkan nilai kesamaan yaitu $41,4 \%$. Yang artinya nilai kesamaan komunitas dari semua stasiun hanya stasiun (Madolin \& Alung Banua), (Madolin \& Muka Kampung), dan (Muka Kampung \& Bunaken Timur) yang masuk dalam kriteria kesamaan komunitas yang berbeda. Odum (1971) menyatakan bahwa nilai kesamaan $<50 \%$ dikatakan berbeda struktur komunitasnya. Hal ini diduga terjadi karena keadaan lokasi penelitian tersebut memiliki beberapa faktor yang mempengaruhi kondisi lingkungan seperti pengaruh dari darat ke laut serta bergantung pada zona habitatnya (Sumual, dkk 2018).

\section{KESIMPULAN}

Berdasarkan hasil analisis data, secara umum dapat disimpulkan bahwa wilayah terumbu karang Pulau Bunaken Taman Nasional Bunaken memiliki potensi ikan karang termasuk dalamnya ikan target. Kondisi ini terlihat dalam jumlah spesies maupun kelimpahan individu yang cukup tinggi dan distribusi hampir merata di semua stasiun pengamatan. Kestabilan komunitas ikan target dalam kawasan terumbu karang Pulau Bunaken Taman Nasional Bunaken cukup stabil dengan melihat nilai indeks keanekaragaman yang dikategorikan kondisi kualifikasinya sedang dan indeks dominansi yang rendah. Jenis Jenis ikan target pada kelima stasiun sebanyak 48 jenis yang dengan total kelimpahan individu sebanyak 568 individu. Jumlah spesies ikan target di stasiun Madolin sebanyak 21 spesies, Alung Banua sebanyak 24 spesies, Sachiko sebanyak 23 spesies, Muka Kampung sebanyak 11 spesies dan Bunaken Timur sebanyak 18 spesies.

Keanekaragaman ikan karang tergolong dalam kategori sedang. Indeks Keseragaman menandakan komunitas tergolong dalam kategori stabil. Indeks dominansi di stasiun BIK 05 tergolong tinggi yang ditandai dengan jumlah individu Ctenochaetus striatus yang jumlahnya paling tinggi, sedangkan di stasiun lainnya rendah. Kelimpahan ikan di stasiun BIK 05 paling tinggi dibandingkan dengan stasiun lainnya. Analisis dengan menggunakan indeks kesamaan komunitas menyatakan terdapat perbedaan antara semua stasiun.

\section{DAFTAR PUSTAKA}

Barbour, G.M., J.K. Burk and W.D. Pitts. 1987. Terrestrial Plant Ecology. New York: The Benyamin/Cummings Publishing Company, Inc

Kendeigh, S. C. 1974. Ecology with special reference to animals and man. Prentice-Hall New Jersey: $474 \mathrm{p}$.

Ludwig, J. A., Reynolds. J.F. 1988. Statistical Ecologycal ; A. Primer on Method Computing. A. Eiley. Interscience Publications. John Wiley and Sons, Inc. Canada. 337hal.

McMellor, S. 2007. A Conservation Value Index to Facilitate Coral Reef Evaluation and Assessment. Department of Biological Sciences. The University of Essex.

Nybakken, J.W. 1992. Biologi Laut: Suatu Pendekatan Ekologis. PT. Gramedia. Jakarta.

Odum, E.P. 1971. Fundamental Ecology, W.B Sauders, Co, London. 574 p.

Odum, E.P. 1998. Dasar-dasar Ekologi (Fundamentals of Ecology). Diterjemahkan oleh $\mathrm{Tj}$. Samingan. Gajah Mada University Press, Yogyakarta.

Rahman, A., \& Sugianti, Y. (2011). Biodiversitas Ikan Karang Di Perairan Kepulauan Karimunjawa. Balai Riset Pemulihan Sumberdaya Ikan Jatiluhur, 1-10. 
Samingan, M.T. (1980). Notes on the Vegetation of the Tidal Areas of South Sumatra. Indonesia With Special Reference to Karang Agung dalam International Social Tropical Ecology. Kuala Lumpur. Hal 1107-1112.

Suheryanto, (2008). Kajian Komunitas Fauna Tanah pada Pertanian Bawang Merah dengan dan Tanpa Aplikasi Pestisida. Universitas Brawijaya. Malang.

Sumual, S., Kusen, J,D., Warouw, V., Paruntu, C., \& Roeroe, K. (2018). Komunitas Ikan Karang Di Pantai Malalayang dan Pantai Meras. Budidaya Perairan, 53-60. 